\title{
Warning against the Indiscriminate Use of a Biological Half-Time Model in Deriving the Critical Concentration of Metals
}

\author{
Minoru SUGITA' and Kenzaburo TsuchryA² \\ 'Department of Public Health, School of Medicine, Tokai University. Isehara 259-11, Japan \\ ${ }^{2}$ School of Medicine \& Institute of Industrial Ecological Sciences, University of Occupational and \\ Environmental Health, Japan. Kitakyushu 807, Japan
}

Abstract: $\quad$ For heavy metals, many studies obtained short biological half-times (BHTs) by administrations of heavy metals. Tsuchiya and Sugita, however, first reported the possibility of a long BHT for cadmium (Cd) calculated from $\mathrm{Cd}$ accumulations in postmortem human organs and tissues by age using a non-linear regression method employing a differential equation. According to their reports, the Cd BHTs (point estimators) were $12.1-22.7$ years by sex, renal cortex and medulla. The minimums and the maximums of the Cd BHTs on the $95 \%$ confidence regions of estimators were 6.9-70.2 years by sex and kidney part. It is presumed that the range of the $95 \%$ confidence region for the individual BHTs of renal Cd exists in a range from a few years to at least 100 years because of large individual variations in exposure, absorption rate and excretion rate. Point estimators of BHTs, however, include the assumption that all subjects have been exposed to the same level of $\mathrm{Cd}$ at the same year of age over a period of decades and have equal absorption and excretion rates of $\mathrm{Cd}$. Therefore, it is not adequate to calculate a safety level for $\mathrm{Cd}$ in the industrial environment or foodstuffs using a value of $\mathrm{Cd}$ BHT (point estimator) based on Cd accumulation applying a mathematical model. BHTs of metals require careful evaluation and must not be used indiscriminately to derive a critical concentration, for example, using a mathematical model.

Key words: biological half-time, cadmium, metal accumulation, critical metal concentration.

(Received 15 February 1988)

\section{Introduction}

The biological half-time (BHT) of a heavy metal is the time required for the concentration or accumulation of the metal to decrease to half the initial amount in a critical organ or total body. The BHT is an important indicator in the study of the toxicity and metabolism of a heavy metal. Many experimental studies (Aberg et al., 1969; Bolanowska et al., 1967; Bolanowska \& Piotrowski, 1968, 1969; Friberg \& Vostal, 1972; Friberg et al., 1974; Kitamura et al., 1976; Nomiyama, 1976; Nomiyama \& Nomiyama, 1976; Nomiyama et al., 1977; Pricket et al., 1950; Rabinowitz \& Wetherill, 1973; Rahola et al., 1971; Yagyu et al., 1975) of heavy metals not only in experimental animals but also in humans using radioisotopes or other methods have revealed shorter BHTs than empirically expected. The authors devised a unique method for estimating the BHT of cadmium (Cd) in the kidney and 
other organs by measuring the concentrations of $\mathrm{Cd}$ and weights of the organs by age using cadavers of humans with no known abnormally high exposure to $\mathrm{Gd}$, and by applying a non-linear mathematical model in which differential equations were employed. The BHTs calculated by this method revealed much longer values than those derived by experimental methods. The results have been reported elsewhere (Tsuchiya \& Sugita, 1971; Tsuchiya et al., 1976; Sugita, 1978; summarized by Dukes \& Friberg, 1971).

The BHTs derived from the accumulation of heavy metals by age are based on point estimators of a non-linear statistical model. A BHT involves, of course, great variation or wide standard deviation, because the concentration of a metal in an organ varies greatly even among individuals of the same age.

For instance, as clearly observed in our previous studies (Tsuchiya et al., 1976; Sugita, 1978) on the BHTs of Cd, Cd concentrations from organs of individuals of the same age indicated a very wide range. It should also be understood that many assumptions have been used to derive the BHTs of Cd by our method, e.g. equal daily intake at the same year of age, absorption rate and excretion rate of every person. Thus, the BHTs we derived show estimated averages which vary so greatly that it is very risky to indiscriminately use these values calculated from an accumulation and excretion model. Nevertheless, the BHT of the renal cortex has been applied to calculate the critical concentration of Cd of human organs, in particular, in the renal cortex (Friberg et al., 1974). A mathematical model using this type of BHT for calculating a safety level for the daily intake of Cd appears to be theoretical and not at all practical.

This paper explains the significance of BHTs derived by our method and warns against their indiscriminate application to a mathematical model.

\section{Statistical Approach}

In order to calculate the BHT of a heavy metal, assuming equal intakes of food, e.g. of trace elements by age with equal absorption and excretion rates, adjusted using an open national calorie intake table (Section of Nutrition, Bureau of Public Health, Ministry of Health and Welfare, 1961), the differential equation

$$
d x=-\lambda x \cdot d t+\beta(t) \cdot d t
$$

is obtained, where $x$ is the amount of the heavy metal accumulation in an organ or tissue, $t$ is age, $\lambda$ is excretion rate, and $\beta(t)$ is absorption amount by age. The excretion rate $\lambda$ is written as

$$
\lambda=\frac{\ln 2}{\tau},
$$

where $\tau$ is biological half-time, and $\ln 2=0.6931471806 \cdots$. It is assumed that 


$$
\beta(t)=\kappa \cdot f(t)
$$

where $\kappa$ is a constant and $f(t)$ is the amount of food intake by age, calculated using the national average calorie intake per capita per day (Section of Nutrition, Bureau of Public Health, Ministry of Health and Welfare, 1961). Equation (1) is written as

$$
\frac{d x}{d t}=-\frac{\ln 2}{\tau} x+\kappa \cdot f(t) .
$$

Equation (2) is solved as

$$
x=\exp \left(-\frac{\ln 2}{\tau} \cdot t\right) \cdot\left[\int \kappa \cdot \exp \left(\frac{\ln 2}{\tau} \cdot t\right) \cdot f(t) d t+c\right],
$$

where $c$ is an integral constant. As an initial condition, we can assume that, when $t=0$, $x=0 . \quad$ Equation (3) is calculated as

$$
\begin{aligned}
x=\kappa & \cdot \exp \left(-\frac{\ln 2}{\tau} \cdot t\right) \\
& \cdot\left[\int \exp \left(\frac{\ln 2}{\tau} \cdot t\right) \cdot f(t) d t-\left[\int \exp \left(\frac{\ln 2}{\tau} \cdot t\right) \cdot f(t) d t\right]_{t=0}\right] .
\end{aligned}
$$

Equation (4) is written as

$$
x=g(t, \tau, \kappa) .
$$

The model of the non-linear regression is

$$
x_{i}=g\left(t_{i}, \tau, \kappa\right)+\varepsilon_{i},
$$

where $\varepsilon_{i}$ is the $i$ th error which is a normally distributed random variable with mean 0 and variance $\sigma^{2}$, and errors $\varepsilon_{i}$ and $\varepsilon_{j}$ are independent $(i \neq j$ and $i, j=1, \cdots, n)$, that is

$$
\varepsilon=\left(\varepsilon_{1} \cdots \varepsilon_{i} \cdots \varepsilon_{n}\right)^{\prime} \sim \mathrm{N}\left(\mathbf{0}, \sigma^{2} \mathbf{I}\right)
$$

When $t_{1}, \cdots, t_{i}, \cdots, t_{n}$ and $x_{1}, \cdots, x_{i}, \cdots, x_{n}$ are obtained, the estimated values of $\tau$ and $\kappa$ can be calculated using non-linear regression analysis (Draper \& Smith, 1966), where $t_{i}$ and $x_{i}$ are the age and the heavy metal accumulation of the $i$ th sample. The sum of the squares of the errors (6) is

$$
\mathrm{S}(\tau, \kappa)=\Sigma \varepsilon_{i}^{2}=\Sigma\left\{x_{i}-g\left(t_{i}, \tau, \kappa\right)\right\}^{2} .
$$


In order to estimate $\tau$ and $\kappa$, simultaneous equations for $\hat{\tau}$ and $\hat{\kappa}$

$$
\left\{\begin{array}{c}
{\left[\frac{\partial \mathrm{S}(\tau, \kappa)}{\partial \tau}\right]_{\tau}=\hat{\tau}, \kappa=\hat{\kappa}=0,} \\
{\left[\frac{\partial \mathrm{S}(\tau, \kappa)}{\partial \kappa}\right]_{\tau}=\hat{\tau}, \kappa=\hat{\kappa}=0}
\end{array}\right.
$$

are solved. The estimated values $\hat{\tau}$ and $\hat{\kappa}$ (point estimators) are the values of $\tau$ and $\kappa$ which minimize $\mathrm{S}(\tau, \kappa)$. The sum of the squares due to residual variation is obtained as

$$
\mathrm{S}(\hat{\tau}, \hat{\kappa})=\Sigma\left\{x_{i}-g\left(i_{i}, \hat{\tau}, \hat{\kappa}\right)\right\}^{2},
$$

and approximately estimated value of $\sigma^{2}$

$$
\hat{\sigma^{2}}=\mathrm{S}(\hat{\tau}, \hat{\kappa}) /(n-2)
$$

The approximate $(1-\alpha)$ confidence region for estimated parameters $(\hat{\tau}, \hat{\kappa})$ can be calculated by finding points $(\tau, \kappa)$ which satisfy

$$
\mathrm{S}(\tau, \kappa)=\mathrm{S}(\hat{\tau}, \hat{\kappa}) \cdot\left[1+\frac{2}{(n-2)} \cdot \mathrm{F}(2, n-2, \alpha)\right],
$$

where $\mathrm{F}(2, n-2, \alpha)$ is the upper $\alpha$ point of $\mathrm{F}$ distribution with 2 and $(n-2)$ d.f. The border of the approximate $(1-\alpha)$ confidence region is drawn on the $\tau$ and $\kappa$ plane (parameter space) surrounding the estimated point $(\hat{\tau}, \hat{\kappa})$. Equation (12) is of the sensible form $\mathrm{S}(\hat{\tau}, \hat{\kappa}) \cdot\left(1+q^{2}\right)$ indicating values of $\mathrm{S}(\tau, \kappa)$ somewhat greater than the minimum value $\mathrm{S}(\hat{\tau}, \hat{\kappa})$, where $q^{2}=2 \cdot \mathrm{F}(2, n-2, \alpha) /(n-2)$. Equation (12) can be written as

$$
\begin{aligned}
{[\mathrm{S}(\tau, \kappa)-\mathrm{S}(\hat{\tau}, \hat{\kappa})]^{1 / 2} } & =\left[\mathrm{S}(\hat{\tau}, \hat{\kappa}) \cdot \frac{2}{(n-2)} \cdot \mathrm{F}(2, n-2, \alpha)\right]^{1 / 2} \\
& =\left[2 \hat{\sigma^{2}} \cdot \mathrm{F}(2, n-2, \alpha)\right]^{1 / 2} .
\end{aligned}
$$

This means, in the case of linear regression, that the confidence region for the estimated parameters thus exists inside a sphere in the estimated space with radius (13).

\section{Materials}

The same data used in reports by Tsuchiya \& Sugita (1971) and Sugita (1978) were used in this study. The materials were organs and tissues of inhabitants of Tokyo and suburbs who underwent autopsy following sudden death by accident and had experienced no known exposure to abnormally high levels of heavy metals during their lifetime. The weights and heavy metal $(\mathrm{Cd}, \mathrm{Pb}$ and $\mathrm{Hg})$ concentrations of the organs and/or tissues were 
determined, and sex and age of cadavers were recorded. In the present study, the data on Gd accumulation in renal cortex and medulla of 475 subjects by age and sex were used. However, some samples could not be subjected to analysis because of inadequate preparation and other reasons.

\section{Results}

The BHT values of $\mathrm{Cd}$ in renal cortex and medulla by sex were calculated using the non-linear regression method. Table 1 shows the estimated values of $\tau$ and $\kappa$ (which are point estimators and types of means), the square roots of estimated values of $\sigma^{2}$, the theoretical maximum accumulations and the ages at which the maximums were found, and the numbers of samples by sex and kidney site. According to Table 1, the estimated BHTs of $\mathrm{Cd}$ in renal cortex and medulla by sex were $12.1-22.7$ years.

The $95 \%$ confidence regions of estimated values $\hat{\tau}$ and $\hat{\kappa}$ were obtained from Equation (12) by sex and kidney site. Figure 1 shows the $95 \%$ confidence region of $\hat{\tau}$ and $\hat{\kappa}$, which is drawn on the parameter space (plane) of $\tau$ and $\kappa$, for female renal cortex. From the $95 \%$ confidence region, the maximum and the minimum of $\tau$ on the border of the confidence region can be calculated. Table 2 shows (a) the maximums and the minimums of $\tau$ on the $95 \%$ confidence regions of estimated parameters $\hat{\tau}$ and $\hat{\kappa}$, and (b) of $\kappa$, (c) the theoretical maximum accumulations, and (d) the ages (at which the maximum accumulations exist) at the maximums and the minimums of $\tau$ by sex and kidney site. According to Table 2, the maximums and the minimums of $\tau$ on the $95 \%$ confidence regions of estimated parameters were 20.7-70.2 and 6.9-11.7 years, respectively. The means and the SDs of the Cd accumulation were calculated by sex and kidney site. Figure 2 shows the means and the SDs of Cd accumulation and the numbers of samples by age group, and the theoretical accumulation curve of the estimated $\tau$ and the curves of the maximum and the minimum $\tau$ at the $95 \%$ confidence region of estimated parameters by age for female renal cortex. Figure 2 indicates that the variation of $\mathrm{Cd}$ accumulation by age group is greater than the difference between the theoretical accumulation curves by age of the maximum and

Table 1. The point estimators of $\tau(B H T)$ and $\kappa$, the square root of the estimated value of $\sigma^{2}$, the theoretical maximum accumulation, and the number of samples by sex and kidney part

\begin{tabular}{|c|c|c|c|c|}
\hline \multirow{2}{*}{ Item } & \multicolumn{2}{|c|}{ Male } & \multicolumn{2}{|c|}{ Female } \\
\hline & Cortex & Medulla & Cortex & Medulla \\
\hline$\hat{\tau}$ (years) & 12.1 & 16.8 & 19.8 & 22.7 \\
\hline$\hat{\kappa}(\mu \mathrm{g} / \mathrm{kcal})$ & 0.391 & 0.0275 & 0.233 & 0.0283 \\
\hline$\sqrt{\widehat{\sigma^{2}}}(\mu \mathrm{g})$ & 7160. & 1040 & 4790 & 835. \\
\hline $\begin{array}{l}\text { Theoretical maximum } \\
\text { accumulation }(\mu \mathrm{g})\end{array}$ & 12800 & 1440. & 11600. & 1560. \\
\hline$[$ age (years)] & {$[54]$} & {$[66]$} & {$[67]$} & {$[70]$} \\
\hline Number of samples & 213 & 211 & 110 & 109 \\
\hline
\end{tabular}




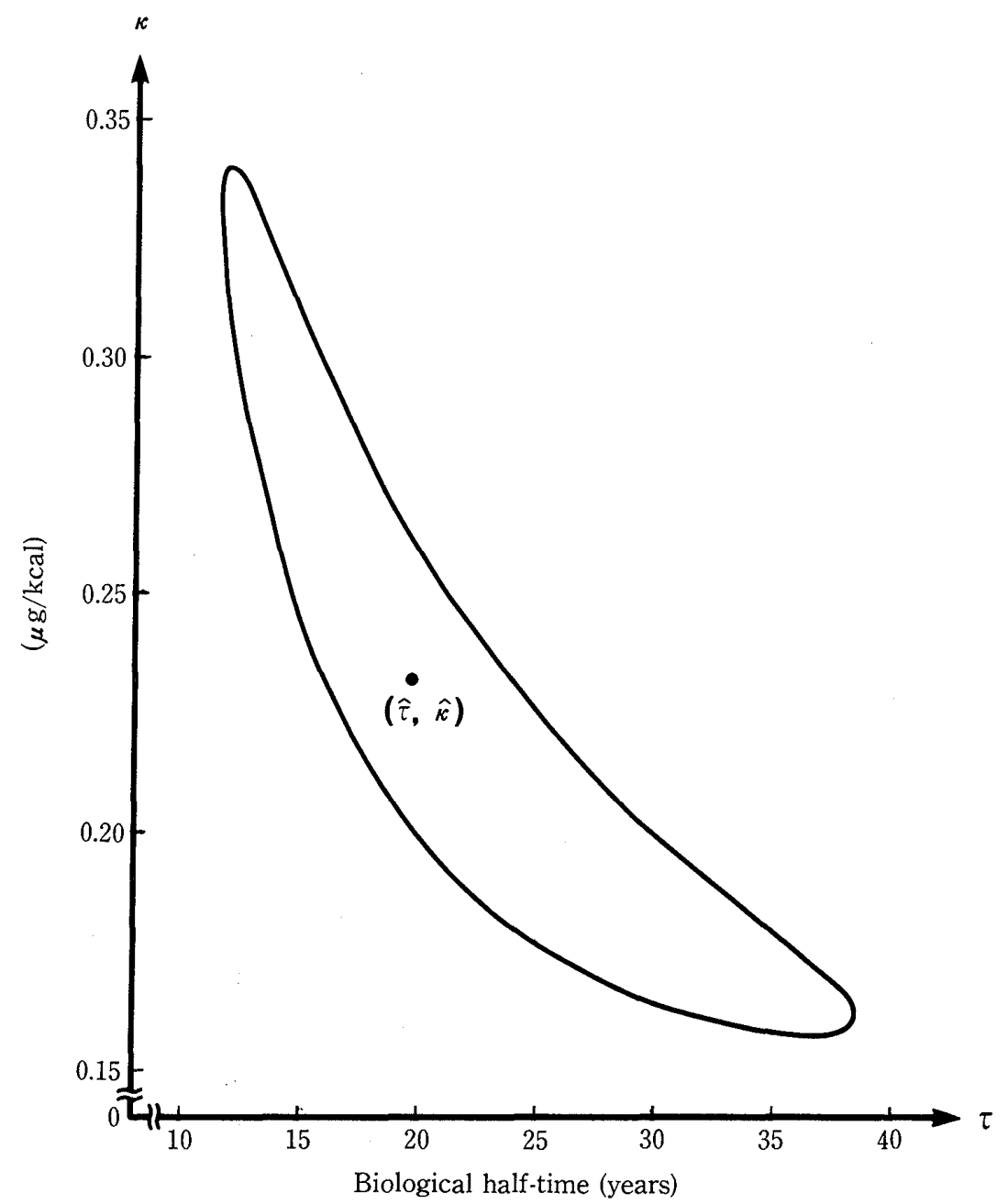

Fig. 1. Confidence region (95\%) for estimated parameters $\ddot{\tau}$ and $\ddot{\kappa}$ of female renal cortex.

Table 2. The maximums and the minimums of $\tau$ on the $95 \%$ confidence regions of estimated parameters $\hat{\tau}$ and $\hat{\kappa}$, and $\kappa$ and the theoretical maximum accumulations at the maximums and the minimums of $\tau$ by sex and kidney part

\begin{tabular}{|c|c|c|c|c|}
\hline \multirow[b]{2}{*}{ Maximum $\tau$} & \multicolumn{2}{|c|}{ Male } & \multicolumn{2}{|c|}{ Female } \\
\hline & Cortex & Medulla & Cortex & Medulla \\
\hline$\tau$ (years) & 20.7 & 40.4 & 38.7 & 70.2 \\
\hline$\kappa(\mu \mathrm{g} / \mathrm{kcal})$ & 0.227 & 0.0178 & 0.162 & 0.0173 \\
\hline $\begin{array}{r}\text { Theoretical maximum } \\
\text { accumulation }(\mu \mathrm{g}) \\
{[\text { age (years) }]}\end{array}$ & $\begin{array}{r}14100 \\
{[71]}\end{array}$ & $\begin{array}{r}1730 . \\
{[80<]}\end{array}$ & $\begin{array}{r}12800 . \\
{[80<]}\end{array}$ & $\begin{array}{r}1790 . \\
{[80<]}\end{array}$ \\
\hline Minimum $\tau$ & Cortex & Medulla & Cortex & Medulla \\
\hline$\tau$ (years) & 6.9 & 7.8 & 11.7 & 11.2 \\
\hline$\kappa(\mu \mathrm{g} / \mathrm{kcal})$ & 0.493 & 0.0472 & 0.333 & 0.0453 \\
\hline $\begin{array}{r}\text { Theoretical maximum } \\
\text { accumulation }(\mu \mathrm{g}) \\
{[\text { age (years) }}\end{array}$ & $\begin{array}{r}12200 . \\
{[38]}\end{array}$ & $\begin{array}{c}1290 . \\
{[41]}\end{array}$ & $\begin{array}{r}10700 . \\
{[52]}\end{array}$ & $\begin{array}{l}1410 . \\
{[51]}\end{array}$ \\
\hline
\end{tabular}




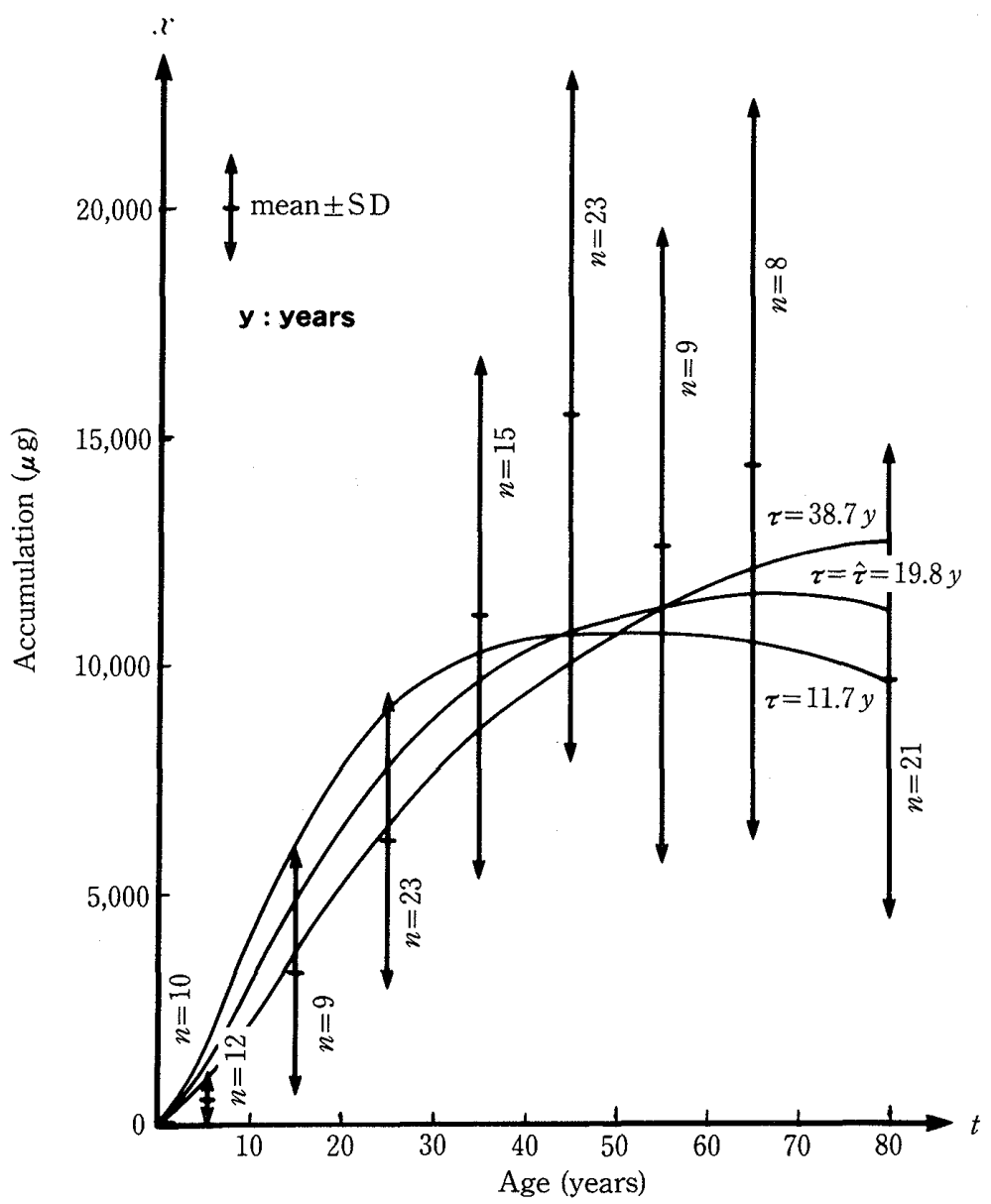

Fig. 2. Cadmium accumulation and theoretical cadmium accumulation curves of $\hat{\tau}$, maximum and minimum $\tau$ of the $95 \%$ confidence region for estimated parameters of female renal cortex by age.

the minimum $\tau$ at the $95 \%$ confidence region of the estimated parameters.

\section{Discussion}

Many experimental studies (Aberg et al., 1969; Bolanowska et al., 1967; Bolanowska \& Piotrowski, 1968, 1969; Friberg \& Vostal, 1972; Friberg et al., 1974; Kitamura et al., 1976; Nomiyama, 1976; Nomiyama \& Nomiyama, 1976; Nomiyama et al., 1977; Pricket et al., 1950; Rabinowitz \& Wetherill, 1973; Rahola et al., 1971; Yagyu et al., 1975) on heavy metals in experimental animals and humans have revealed short BHTs, using a model for time reaching half that of the initial stage. The authors developed a method for estimating the BHT from the accumulation of a heavy metal according to age using postmortems of humans with no known abnormally high exposure to heavy metals. The method uses a nonlinear mathematical model employing differential equations. At a meeting of the Subcommittee on the Toxicology of Metals, ICOH, which was held in Salanchev Briag, Bulgaria, in September 1971, Tsuchiya and Sugita first reported (summarized by Dukes \& Friberg, 1971) that the BHT calculated from accumulation of Cd by age using human postmortem 
organs was much longer than the BHTs obtained by experimental methods. Tsuchiya \& Sugita (1971) described a long BHT of Cd in renal cortex. Before the Subcommittee Meeting in Salanchev Briag, at the Rochester Symposium on cadmium in the environment, U. S. A., in June 1971, Tsuchiya presented a paper which showed a long BHT of Cd in renal cortex and other organs. Based on the idea of the long BHT of Cd accumulation presented by Tsuchiya at the Rochester Symposium, Kjellström (1971) reported the relationship between the long BHT and autopsy data of Cd in renal cortex. Furthermore, Kjellström discussed the Maximum Allowable Concentration (MAG) of Gd for industrial air and the safety margin of Cd for the general population based on the long BHT of Cd. Sugita (1978) reported that the short BHT of heavy metal administration was associtated only with the shallow compartments of organs, and that the long BHT without experimental administration of heavy metal was due to a circuitous route taken naturally by the metal from the shallow to deep compartments.

From Equation (12), the approximate 95\% confidence regions for estimated parameters $(\hat{\tau}, \hat{\kappa})$ can be obtained on the parameter space $(\tau, \kappa)$. Table 2 indicates that the range of BHTs in renal $\mathrm{Cd}$ on the basis of the $95 \%$ confidence regions for estimated parameters is $6.9-70.2$ years. Figure 2 shows that the variation of $\mathrm{Cd}$ accumulation by age group is greater than the difference between the theoretical accumulation curves by age of the maximum and the minimum BHTs on the $95 \%$ confidence region of estimated parameters. This means that the variation among sets of individual parameters is greater than that among the values on the confidence region for estimated parameters.

Now let us discuss the confidence region for individual parameters $\tau$ and $\kappa$. We know that a standard deviation is $\sqrt{n}$ times as large as the standard error. By analogy, from Equation (13), we can presume that the range of the approximate confidence region for individual parameters is $\mathrm{O}(\sqrt{n})$ \{i.e. order of $\sqrt{n}$ \} times as large as that for estimated parameters. The confidence region for individual parameters, however, cannot be calculated exactly in the non-linear situation. Nevertheless, it is not inadequate to note approximately that the range of the $95 \%$ confidence region for the individual BHTs of renal Cd may exist in the range from a few years to 100 years or more. The reason for such a wide range in individual BHTs is due to large individual variations of exposure, absorption and excretion rates, etc., as mentioned. On the other hand, point estimators of BHTs are calculated with many more assumptions including equal exposure by age and equal absorption and excretion rates.

Therefore, it is not adequate to calculate a safety level for $\mathrm{Cd}$ in an industrial environment or for foodstuff using a value of Cd BHT (point estimator) based on Gd accumulation applying a mathematical model. BHTs of metals must be carefully evaluated and should not be used indiscriminately for deriving a critical concentration, for example, in a mathematical model.

If a long BHT, especially an upper limit of individual BHT is used, the safety level of daily intake, for example, may result in zero exposure. On the other hand, if a short 
BHT obtained from experimental study is used, the safety level may result in much greater exposure.

\section{References}

Aberg, B., Ekman, L., Falk, R. et al. (1969): Metabolism of methylmercury (203 Hg) compounds in man. Arch. Environ. Hlth., 19: 478-484.

Bolanowska, W., Piotrowski, J. \& Trojanowska, B. (1967): Kinetics of distribution and excretion of lead (Pb210 ) in rats. I. The distribution of a single intravenous dose. Med. Pracy, 18: 29-41. (in Polish with English summary)

Bolanowska, W. \& Piotrowski, J. (1968): Kinetics of distribution and excretion of lead $(\mathrm{Pb}-210)$ in rats. II . Excretion of a single intravenous lead dose. Med. Pracy, 19: 133-142. (in Polish with English summary)

Bolanowska, W. \& Piotrowski, J. (1969): Kinetics of distribution and excretion of lead $(\mathrm{Pb}-210)$ in rats. III. The retention and excretion of lead given in daily intravenous injections. Med. Pracy, 20: 494-503. (in Polish with English summary)

Draper, N. R. \& Smith, H. (1966): Applied Regression Analysis. John Wiley \& Sons, New York. 263301.

Dukes, K. \& Friberg, L. (1971): Absorption and excretion of toxic metals. Nord. Hyg. Tidskr., 53: 70104.

Friberg, L. \& Vostal, J. (1972): Mercury in the Environment. CRC Press, Cleveland. 215 pp.

Friberg, L., Piscator, M., Nordberg, G. F. et al. (1974): Cadmium in the Environment. 2nd ed. GRC Press, Cleveland. 248 pp.

Kitamura, S., Kondo, M., Takizawa, Y. et al. (1976): Mercury. Kodansha, Tokyo. 426 pp. (in Japanese)

Kjellström, T. (1971): A mathematical model for the accumulation of cadmium in human kidney cortex. Nord. Hyg. Tidskr., 53: 111-119.

Nomiyama, K. (1976): Critical concentration and biological half-time of cadmium in the renal cortex of humans. Kankyo Hoken Report (Environmental Health Report), 36: 62-65. (in Japanese)

Nomiyama, K. \& Nomiyama, H. (1976): Biological half time of cadmium in rabbits. Jpn. J. Hyg., 31: 78. (in Japanese)

Nomiyama, K., Nomiyama, H. \& Taguchi, T. (1977): Biological half time of cadmium in mice. Jpn. J. Hyg., 32: 128. (in Japanese)

Prickett, C. S., Laug, E. P. \& Kunze, F. M. (1950): Distribution of mercury in rats following oral and intravenous administration of mercuric acetate and phenylmercuric acetate. Proc. Soc. Exp. Biol. Med., 73: $585-588$.

Rabinowitz, M. B. \& Wetherill, G. W. (1973): Lead metabolism in the normal human: Stable isotopes studies. Science, 182: 725-727.

Rahola, T., Aaran, R. K. \& Miettinen, J. K. (1971): Half-time studies of mercury and cadmium by whole body counting. I. A. E. A. Symposium on the Assessment of Radioactive Organ and Body Burdens, Stockholm, November 22-26, 1971. (in Assessment of Radioactive Contamination in Man, I. A. E. A., Vienna, 1972, p. 553).

Section of Nutrition, Bureau of Public Health, Ministry of Health and Welfare (1961): Newly Adopted Nutritional Requirement of the Japanese. Daiichi Shuppan Book Co., Tokyo. 43 pp. (in Japanese)

Sugita, M. (1978): The biological half-time of heavy metals - The existance of a third, "slowest" component. Int. Arch. Occup. Environ. Hlth., 41: 25-40.

Tsuchiya, K. \& Sugita, M. (1971): A mathematical model for deriving the biological half-life of a chemical. Nord. Hyg. Tidskr., 53: 105-110.

Tsuchiya, K., Sugita, M. \& Seki, Y. (1976): Mathematical derivation of the biological half-time of cadmium in human organs based on the accumulation of the metal in the organs. Keio J. Med., 25: 73-82. 
Yagyu, H., Ohi, G., Nishigaki, S. et al. (1975): Studies on biological half life of alkylmercury compounds in rats and mice. Jpn. J. Hyg., 30: 55. (in Japanese)

金属の生物学的半減期モデルの応用に関する問題点

杉 田 稔 ${ }^{1}$ 土屋 健三郎 ${ }^{2}$

'東海大学医学部公衆衛生学教室 '産業医科大学学長

要 旨： 実験により重金属の生物学的半減期 (BHT) を求める方法で，短いBHT を報告した研究は 多数ある。一方，土屋と杉田はヒトの臓器や組織中のガドミウム (Cd) 蓄積量により, 微 分方程式を含有する非線型回帰法を使用して長い Cd の BHT を算出し, それを初めて報 告した。それによると腎皮質と䯣質 (男，女)の Cd の BHT (点推定值)の範囲は 12.1 22.7 年であった。このデー夕を使用して, 推定母数の $95 \%$ 信頼限界上の Cd の BHTの 最小值と最大值を 6.9-70.2 年と推定した。.さらに，その Cdの BHT の個人値の $95 \%$ 信 頼限界はおおよそ数年から 100 年以上の広い範囲内にあると推測された。このような $\mathrm{BHT}$ 個人值の広範囲の理由は $\mathrm{Cd}$ の摂取量, 吸収率や排泄率等の固体差がかなり大きい と考えられていることである。一方, それらの固体差を無視した平均值として, 蓄積量を もとにした Cdの BHT の点推定值が算出される.したがって，Cdの労働環境や食品の安 全基準の算出にその点推定値としての BHT を使用することは不適当である.このことは, 金属のBHT を慎重に評価吟味して，軽率な使用を慎むべきであることを示している.

J. UOEH (産業医大誌), 10 ( 2): 179-188 (1988) 